\title{
Tarihi Çevrelerde Doğal Taş Kullanımı; Trabzon "Ortamahalle" Örneği
}

\section{Usage of Natural Stone in Historical Environments: Trabzon "Ortamahalle" Example}

\begin{abstract}
Hilal KAHVECI ${ }^{1} *$ \& Makbulenur BEKAR ${ }^{2}$
Geliş / Received: 27/10/2021

Revize / Revised: 08/11/2021

Kabul / Accepted: 15/11/2021

$\ddot{\text { ÖZ }}$

Tarihi çevreler geçmişte yaşanan sosyal, kültürel yaşamın izlerini günümüze taşıması ve insan-doğa-yapı arasında kurulan doğrudan ilişkiler nedeniyle önemli bir arşiv niteliğindedir. Kentleşmeyle birlikte bazı tarihi çevrelere yapılan müdahaleler artmış restorasyon ve koruma işlemleri ile kullanıma açılmıştırlar. Tarihi dokuları oluşturan yapısal ve bitkisel bileşenler insanların belleğinde izlenimler oluşturmakta kent kimliği ve okunabilirlik algısında etkili olmaktadır. Bu dokuların yapısal elemanlarının büyük bölümü doğal taş kullanımıyla inşa edilmektedir. Tarihi sokaklar ise doğal taşın en güzel kullanım yerlerinden biridir. Bu bağlamda çalışma alanı Trabzon ilinin en eski tarihi mahallerinden olan Ortamahalle tarihi sokağı seçilmiştir. Bu çalışmanın amacı, tarihi bir sokak olan Trabzon Ortamahalle'de eski dönemlere ait yapılaşmada kullanılan doğal taş elemanların peyzaj değerini ortaya koymak ve kentsel alanların sürdürülebilirliğine katkılarını vurgulamaktır. Çalışmada estetik, özgün, işlevsel, hatırlanabilir, etkileyici, uyumlu, doğal, sürekli, algılanabilir, bütünlük etkisi parametreleri arasındaki önem düzeyini belirleyebilmek için faktör analizi, parametrelerin istatistiksel olarak anlamlı olup olmadığını belirlemek için 'One-Sample T' testi uygulanmış, 'One-Sample $T$ ' testi ve parametrelerin kendi aralarındaki ilişkiyi görebilmek için de korelasyon analizi yapılmıştır. Sonuç olarak doğal taşın kullanım amaç ve alanları ile peyzaj değeri arasında $\mathrm{P}<0,01$ değerine göre anlamlı bir ilişki olduğu saptanmıştır. Çalışma sonucunda elde edilen bulgular doğrultusunda gelecekte yapılacak olan tasarım, uygulama ve çalışmalara dair önerilerde bulunulmuştur.
\end{abstract}

Anahtar Kelimeler- peyzaj tasarımı, doğal taş, tarihi sokaklar

\begin{abstract}
Historical environments have an important archive value as they carry the traces of the social and cultural life in the past to the present and due to the correct relations established between human-nature-structure. With urbanization, the interventions to some historical environments have increased, and these environments have been put into use with restoration and protection processes. Structural and plant components that compose historical textures create impressions in people's memory and are effective in the perception of urban identity and readability. Most of the structural elements of these textures are built with the use of natural stone. Historical streets are one of the most beautiful places of use of natural stone. In this context, Ortamahalle historical street, which is one of the oldest historical districts of Trabzon province, was chosen as the study area. This study aims to reveal the landscape value of the natural stone elements used in the construction of ancient times in Trabzon Ortamahalle, which is a historical street, and to emphasize their contribution to the sustainability of urban areas. The factor analysis was used to determine the level of importance among the parameters of aesthetic, original, functional, memorable, impressive, harmonious, natural, continuous, perceptible, integrity effect. The 'One-Sample T' test was used to determine whether the parameters were statistically significant, and correlation analysis was used to see the relationship between the 'One-Sample $\mathrm{T}^{\prime}$ test and parameters themselves. As a result, it was determined

\footnotetext{
1* Sorumlu Yazar, Dr. Öğr. Üyesi, Bilecik Şeyh Edebali Üniversitesi, Güzel Sanatlar ve Tasarım Fakültesi, İç Mimarlık ve Çevre Tasarımı Bölümü, hilal.kahveci@bilecik.edu.tr, (https://orcid.org/0000-0002-4516-7491)

${ }^{2}$ Arş. Gör., Karadeniz Teknik Üniversitesi, mnurbekar@gmail.com, (https://orcid.org/0000-0003-4511-1284)
} 
that there is a significant relationship between the purpose and areas of use of natural stone and the landscape value according to the $\mathrm{P}<0.01$ value. In line with the findings obtained as a result of the study, suggestions were made for future work regarding the design, implementation, and studies.

\section{Keywords- Landscape design, natural stone, historical street}

\section{Gİiş}

Kentsel alanlarda yer alan tarihi binalar, tarihi sokaklar ve meydanlar bir araya gelerek kentin tarihi çevresini oluşturmaktadır. Tarihi çevreler korundukları, yaşatıldıkları ve yeniden işlev kazandırıldıkları zaman geçmişle gelecek arasında hem bağ kurmakta hem de önemli bir turizme kaynak olmaktadır (Kan, 2009:1). Yüzyıllardan bu yana anıtsal tarihi yapıların çoğunun yapı malzemesinin dayanımı yüksek doğal taş olması, günümüze kadar gelen bu kültür varlıklarını ölümsüz kılan ve ayakta kalmasında etkili olan bir faktördür (Hasbay ve Hattab, 2017: 25). Bu yapılar ait oldukları dönemlerin sosyal ve kültürel yapısını yansıtarak kentlerin kimliğini oluşturma açısından önemli birikimlerdir. Tarihi yapıların ve doğal çevrelerinin birlikte korunması kentin sahip olduğu kimliği korumasına ve bulundukları dokunun sürdürülebilirliğine katkı sağlamaktadır (Büyükmıhçı vd., 2015: 163). Günümüzde tarihi dokular içerisinde ayakta kalan ve bizleri hayran bırakan birçok yapıda, estetikle sanatın bütünleştiği tarihin en önemli sessiz tanıkları, görkemli ve soylu doğal taş yapılar mevcuttur (Carta vd. 2005:278; Raju ve Ravinhar, 2021: 6341). Antik kentler, anıtlar, heykeller bu açıdan değerlendirildiğinde doğal taşlar; insanoğlunun varoluşundan bugüne kadar geçen bütün dönemlerin yazılı ve görsel belgeleridir (Yavuz, 2010:69)

\section{GEÇMIŞTEN GÜNÜMÜZE DOĞAL TAŞ VE KULLANIM ALANLARI}

Doğal taşlar, geçmişten bugüne insan hayatında vazgeçilmez bir yere sahip olmuştur. İnsan yaşamı, barınma, korunma, duygularını ve mesajlarını geleceğe aktarma, sonsuz yolculuğunda bedenini emanet etmeye kadar, sağlamlığın ve güven hissinin simgesi olan taş ile etkileşim halindedir (Hasbay ve Hattab, 2017: 25). Sürdürülebilir kent kavramının gündeme gelmesiyle geçmişte de mimari birçok alanda kullanılan dış etkilere dayanıklı, şekil verilebilir, çevreye zararlı maddeler yaymayan ve geri dönüşüm özelliği olan doğal taşların önemi artmıştır. Ekolojik bir malzeme olan doğal taştan inşa edilmiş yapılar; kısıtlı doğal kaynakların kullanımı açısından sürdürülebilir mimari akımını destekler nitelikte olup; geçmişin, bugünün ve yarının mimarisi arasındaki ilişkiyi ortaya koyar (Yavuz, 2010:144; Siegesmund ve Snethlage, 2011; Gürdal ve Acun Özgünler, 2016:27-29; Alptekin, 2021: 304-305). İlk çağlarda barınak amacıyla kullanılan doğal taşlar zaman içinde işlevsel ve estetik olarak birçok alanda kullanılan bir materyal haline dönüşmüştür (Yüksel ve Eraslan, 2019: 70). Doğal taşlar, tarihi yapılarda tasarımcı tarafından güç ve dayanıklılık sembolü olarak, kalıcı eserler yapmak üzere kullanılmış olsa da yalnızca dayanıklılık özellikleri ile değil, sahip oldukları renk ve doku çeşitlilikleri ile de estetik açıdan tercih edilmişlerdir (Gürdal ve Acun Özgünler, 2016). Bu özellikleri ile tarihi yapılarda, kolonlarda blok halinde, taşıyıcı duvarlarda örgü malzemesi olarak, dış yüzey kaplama malzemesi olarak cephelerde, zemin kaplama malzemesi olarak da döşeme kaplamalarında çokça kullanıldığına rastlanmaktadır (Hasbay ve Hattab, 2017: 25). Anadolu topraklarında da özellikle Eski Yunan, Roma, Bizans, Selçuklu ve Osmanlı dönemlerinde doğal taştan yapılmış sayısız eser bulunmaktadır (Çelik, 2003:4)

Binalarda yapı taşı olarak kullanılan doğal taşlar kesme taş ve molozlardır. Diğer önemli bir yapı elemanı olan duvar yapımında taşlarının seçiminde, dekoratif oluşunun yanı sıra aşınmazlığı, sertliği ve ucuz olması da dikkate alınmaktadır (Yavuz, 2010: 42). Yapıların döşeme ve kaplamalarında genellikle mermer, traverten, granit, andezit, bazalt ve tüf gibi doğal taş ürünleri kullanılmaktadır. İç ve dış mekânlarda döşeme ve kaplama malzemesi olarak yüzeyleri honlama, cilalama, alevle yakma, eskitme, kumlama, çekiçleme, doldurma ve asitle yıkama ile şekillendirilerek işlenen doğal taşlar daha fazla kullanılmaktadır. Moloz ve kesme taşlardan (kumtaşı, kireç taşı, andezit, kayrak vb.) karışımlar genelde binaların temelinde ve duvarlarında, şekil verilen parke ve bordür taşı olarak da yol ve kaldırımlarda kullanılmaktadır (Karahan, 2018: 11). Özellikle kentsel alanlarda yapılar, duvarlar, yer döşemeleri, çeşmeler, havuzlar, dekoratif elamanlar vb. peyzaj yapılarında kent kimliğini yansıtmaktadırlar (Çelik ve Kavuşan, 2001:77-85). Bunlara ek olarak yol ve kaldırım döşemesi, bordür taşı, kent mobilyaları, duvar yapımı, duvar kaplaması, merdiven basamağı, çatı örtüsü, iç ve dış dekorasyon, peyzaj tasarımı, bahçe adım taşı, iç mekân döşeme, mutfak ve banyolarda da kullanımı giderek artmaktadır. 


\begin{tabular}{|c|c|c|}
\hline & $\begin{array}{l}\text { BŞEÜ Sosyal Bilimler Dergisi } \\
6(2), 333-347,2021\end{array}$ & $\begin{array}{r}\text { BSEU Journal of Social Sciences } \\
\text { https://doi.org/10.33905/bseusbed.1015396 }\end{array}$ \\
\hline $\begin{array}{l}\text { BILECIK SEYY EDEBALI } \\
\text { ONIVESITES }\end{array}$ & $e-I S S I$ & V:2548-088X (https://dergipark.org.tr/tr/pub/bseusbed) \\
\hline
\end{tabular}

\section{PEYZAJ, TARIHİ ÇEVRELER VE DOĞAL TAŞ KULLANIMI}

Peyzajlar aslında doğal ve kültürel imajlar olup belli şeyleri temsil eden, yapılandıran çevresel elemanlar bütünüdür denilebilir. Doğadaki birçok malzeme, yüzey, toprak, taş, vejetasyon, ölü örtü gibi doğal kaynaklarla temsil edilmektedirler (Erdoğan, 2006:69-77). Dolayısı ile kültürel peyzajlar ve tarihi çevreler birçok doğal ve kültürel ögeyi içinde barındırır. Tarih, kültür ve peyzaj bileşenleri birleşerek simgeleşir (Kap Yücel ve Salt, 2018:40-53). Barındıkları tarihi yapıların ortak özelliği ise geçmişteki teknik ve teknolojilerle inşa süreçlerinin yaşanmasıdır. Erdoğan (2006) Selçuklu döneminde doğal yapı malzemeleri olan taş ve tuğla ile inşa edilmiş anıtsal yapılar ve ilk külliye örneklerinin kent silüetindeki belirleyici yapılar olduğunu vurgulamıştır (Erdoğan, 2006:6977). Ayrıca doğal taşların peyzaj düzenlemelerinde kullanımı, düzenlemelerin görsel kalitesini artırmakta, insandoğa yakınlaşmasında da önemli bir işlev üstlenmektedir. Tarih boyunca pek çok uygarlık (Eski Mısır, Orta çağ bahçeleri, Japon bahçeleri vb.) peyzaj mimarlığı çalışmalarında doğal taşları kullanmış olup (Şekil 1-2-3), günümüzde de özellikle gelişmiş ülkelerde (Avrupa ülkelerinin kentleri gibi) bu eğilim artarak devam etmektedir (Altınçekiç, 2001: 49). Dünyada ve Türkiye de doğal taşın kullanılmış olduğu oldukça önemli yapitlar bulunmaktadır. Bunlardan bazı örnekler ise görsellerde verilen Girne Kalesi, Roma Trevi Çeşmesi, Floransa meydanları ve Trabzon kent surlarıdır (Şekil 1-2-3).
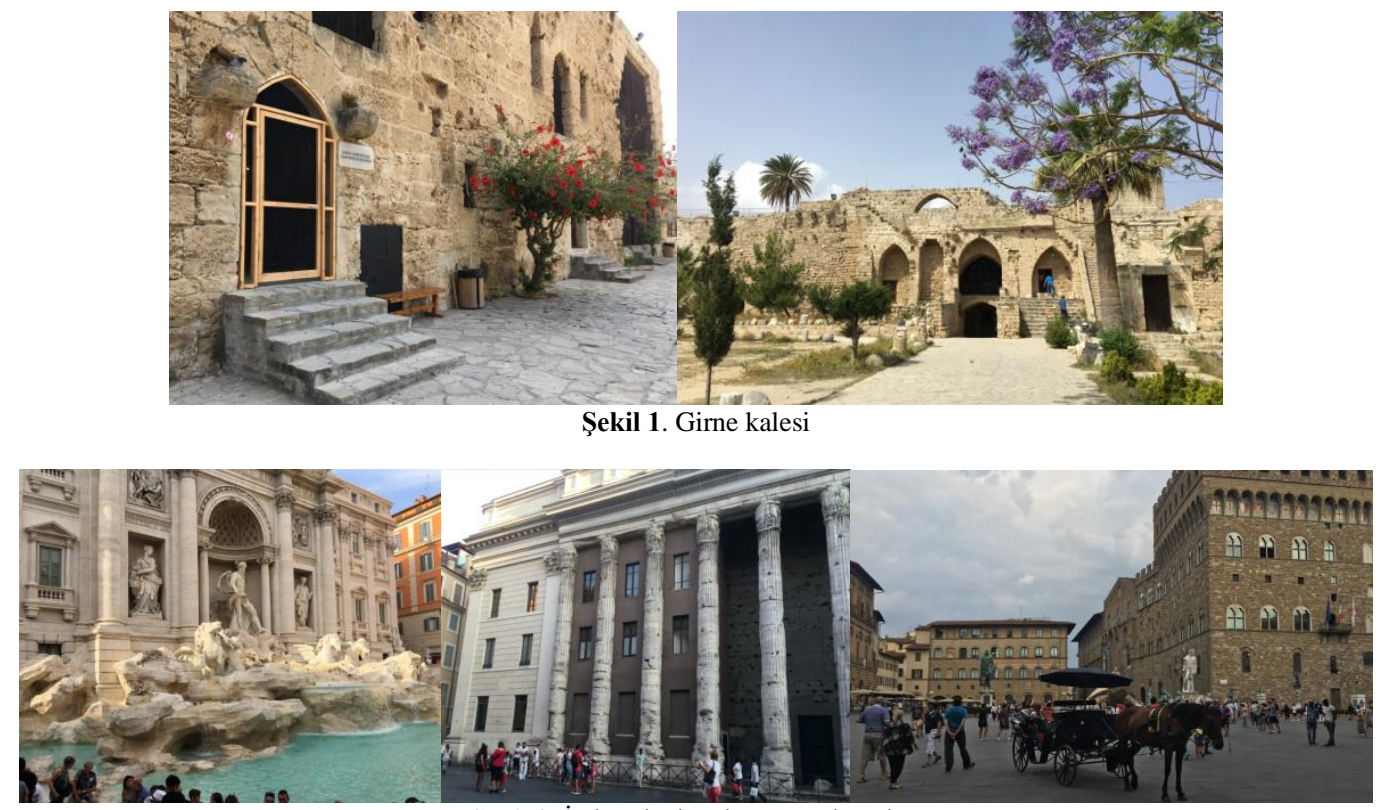

Şekil 2. İtalya'da doğal taş uygulamaları

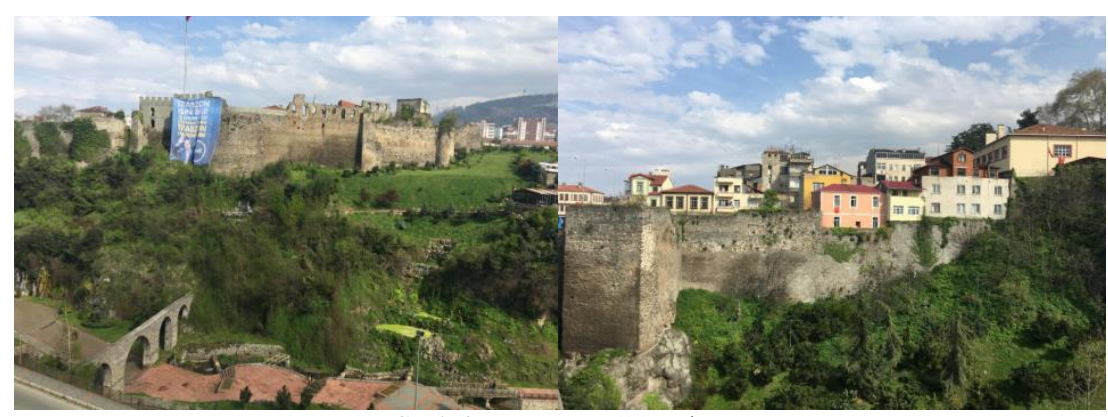

Şekil 3. Trabzon tarihi surları 


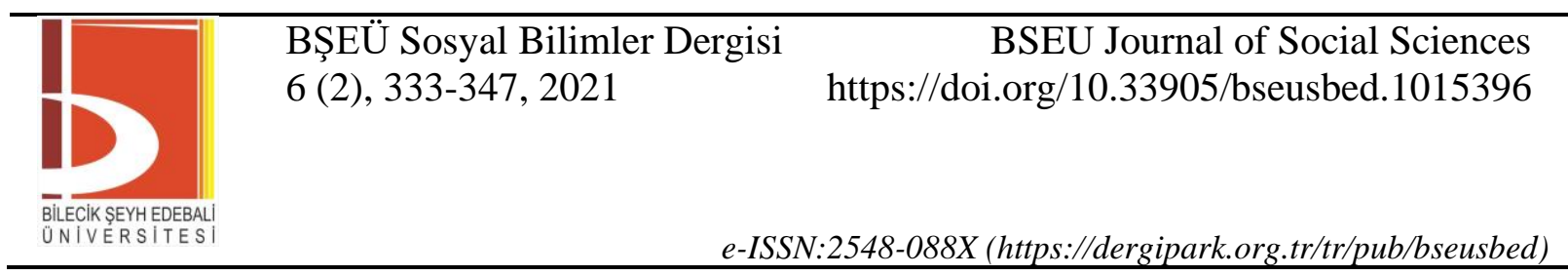

\section{IV. ÇALIŞMA ALANI VE YÖNTEM}

\section{A. Çalışma Alanı}

Çalışmanın ana materyalini Doğu Karadeniz bölgesi Trabzon ili Akçaabat ilçesinin Ortamahalle olarak isimlendirilen tarihi mekânı oluşturmaktadır. Büyük bir bölümü kentsel sit olan tarihi mahalle Trabzon'un $13 \mathrm{~km}$ batısında ve ilin nüfusu ile en büyük ilçesi Akçaabat İlçesi'nde yer almaktadır. Akçaabat, Trabzon ilinin 18 ilçesinden biridir (Bekar vd., 2017: 489-490) (Şekil 4).

Evleri ve tarihi sokakları ile Ortamahalle Akçaabat'ın en eski üç mahallesinden biridir. Mahallenin karakteristik özelliklerinden biri ise birbirlerinin manzarasını kesmeyen yüzyıllık konaklarla çevrili olmasıdır. Evlerin hepsi bahçe içindedir ve bu bahçeleri sokağa sırtlarını dönmüş yapıların cepheleri bol güneşli bahçelere yönlendirilmiştir. Yapı malzemesi olarak taş, ahşap ve kiremit kullanılmıştır. Genellikle evlerin zemin katları yığma taştır. Orta mahalle gerek mimari kimliği gerekse taş işçiliği açısından geleneksel Türk Mimarisinin özgün örneklerinden biridir (URL-1) (Şekil 5).

Çalışma alanı klimatik açıdan Doğu Karadeniz bölgesi kıyı kesiminin ılıman iklim özelliklerini yansıtmaktadır. Topoğrafik olarak kuzeyden güneye gidildikçe yükseklik ve eğim artmakta, yerleşim düzeninde düzlük alanlar oldukça yetersiz kalmaktadır. Bu nedenle Ortamahalle'de konutlar dik yamaçlarda ve doğu yönüne doğru planlanmışlardır (Bekar vd., 2017: 489-490). Geleneksel Doğu Karadeniz Evi, taş duvarlı bir alt yapı ve üstünde genellikle ahşaptan yapılmış bir ya da iki kattan oluşmaktadır (Aydın ve Alemdağ, 2014: 396). Doğal taş kullanılan geleneksel evlere örnek Ortamahalle evleri bu kapsamda çalışma alanı olarak seçilmiştir (Şekil 4, 5).

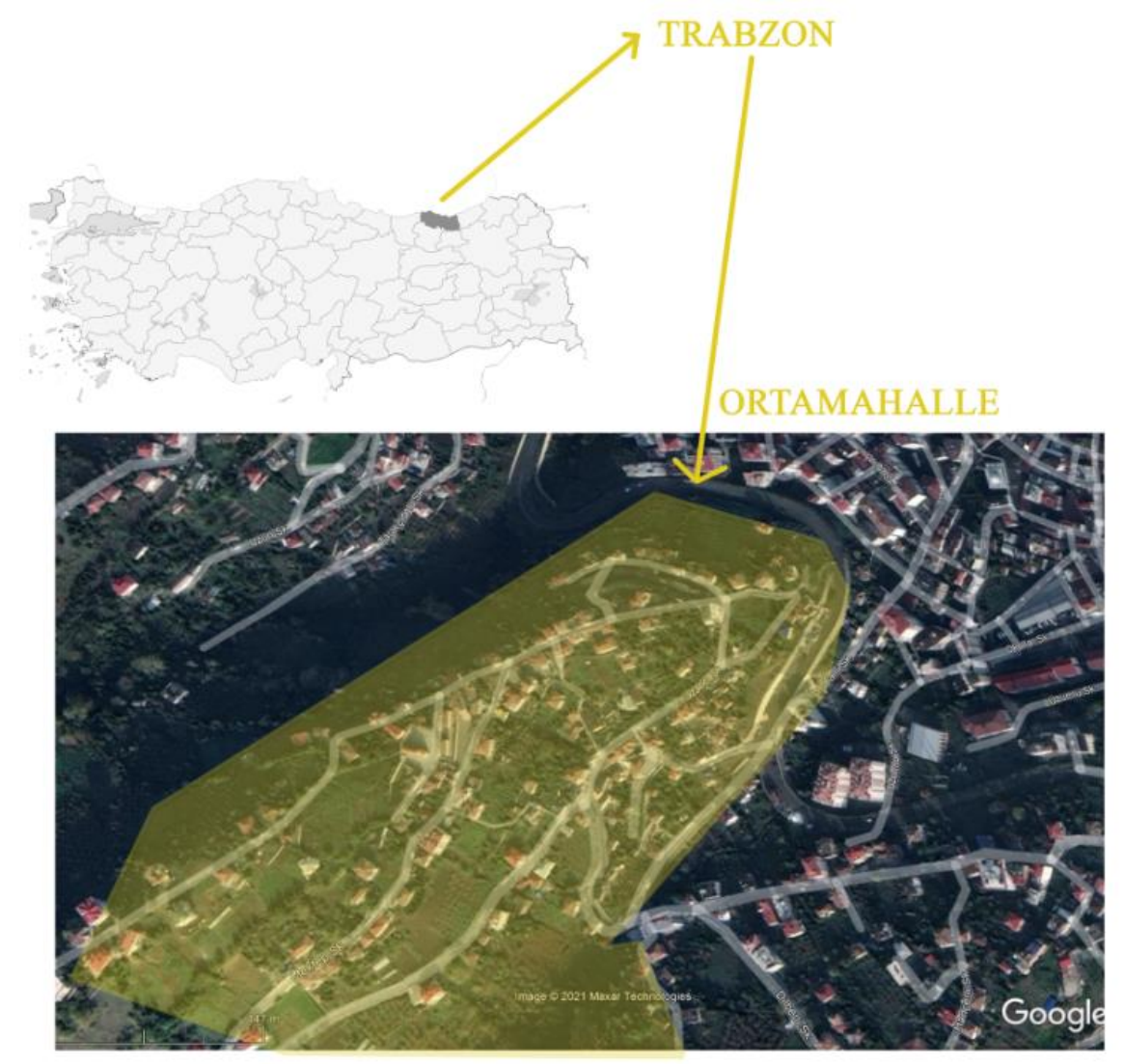

Şekil 4. Trabzon Ortamahalle haritada konumu 


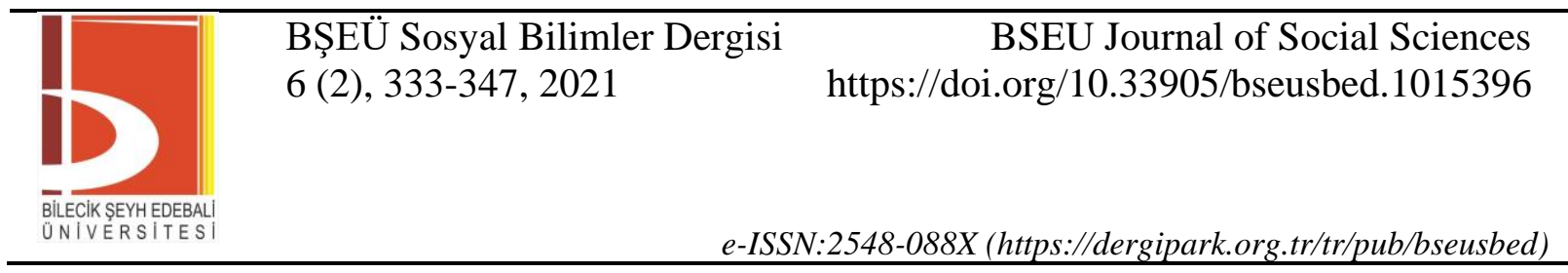

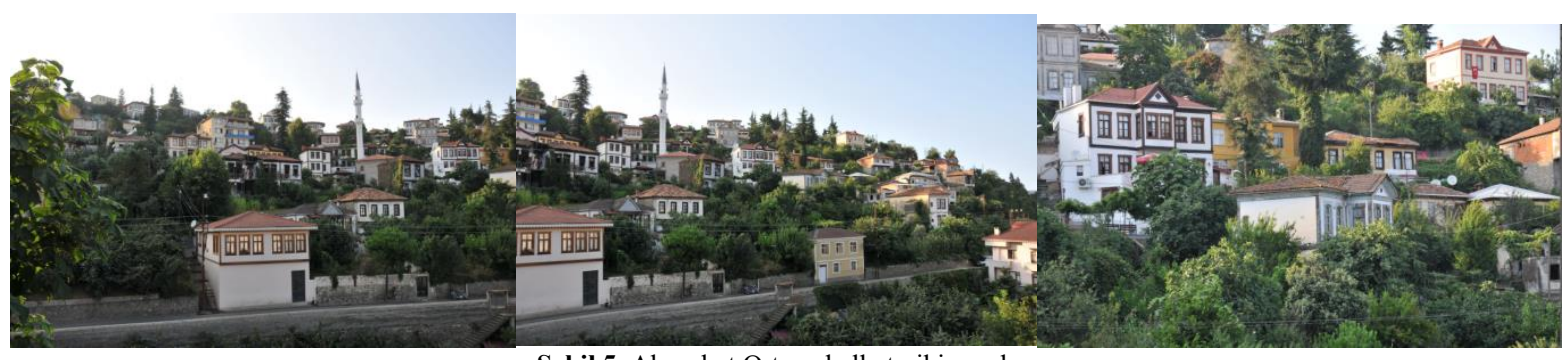

Şekil 5. Akçaabat Ortamahalle tarihi yapıları

Yapılan bu çalışma kapsamında çekilen fotoğrafların nerelerden çekilmesi ve hangi noktalara odaklanılması gerektiğini saptayabilmek adına Lynch (2010)' in 5 elementinden faydalanılmıştır (Lynch, 2010: 20-159). Alan gözlem ve arazi çalışmaları neticesinde yollar, düğüm noktaları, sınır elemanları, önemli noktalar ve yollar tespit edilip haritalandırılmıştır (Şekil 6). Çalışmanın yöntemine uygun olacak şekilde bu bölgelerden fotoğraflar çekilmiştir.

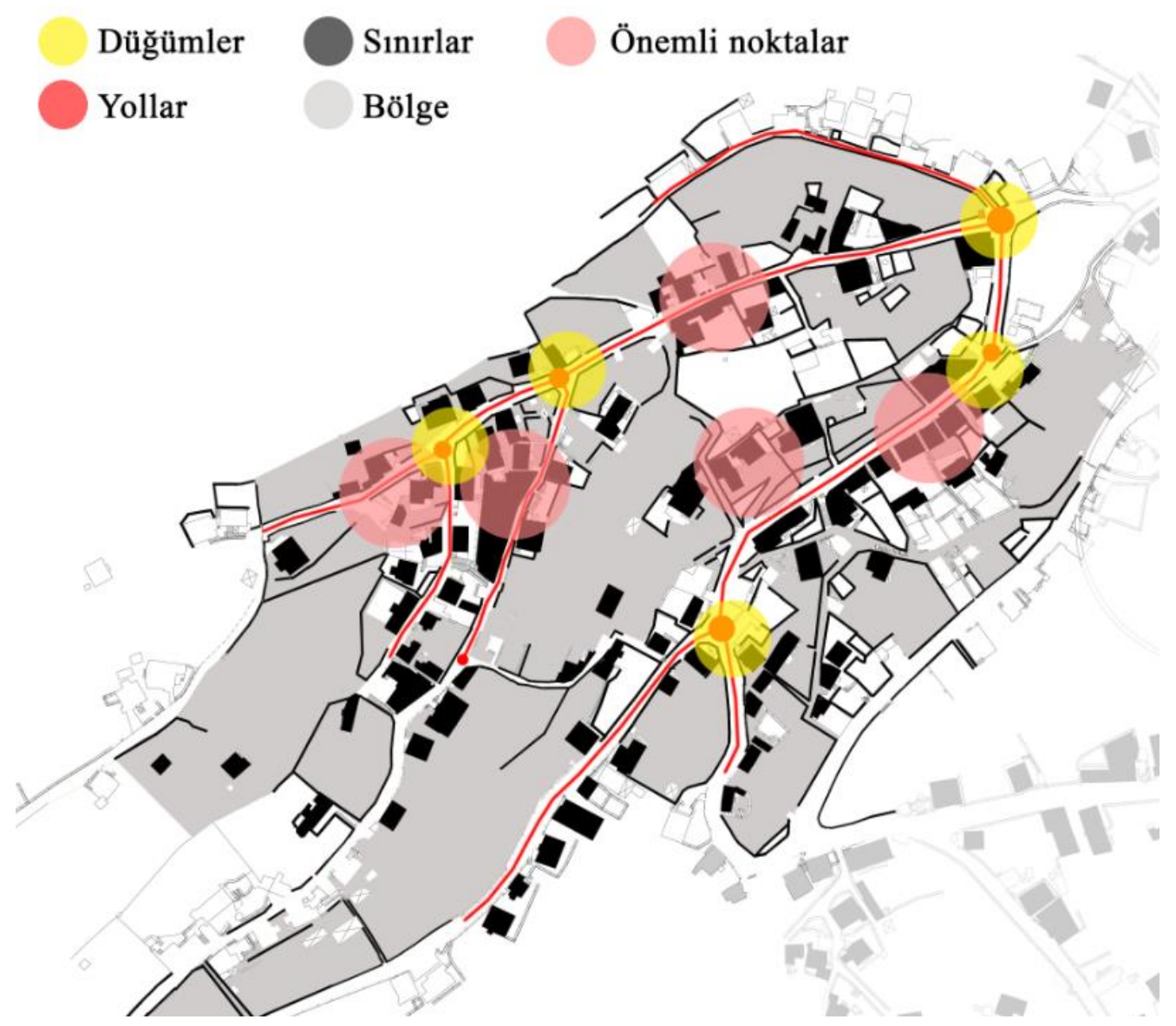

Şekil 6. Lycnch'in 5 parametresi ve orta mahalle (Lynch, 2010)

\section{B. Yöntem}

Yöntem birbirini izleyen 3 aşamadan oluşmaktadır. Birinci aşamada; öncelikli olarak literatür çalışması yapılmış; Altınçekiç (2001), Gürdal ve Özgünler (2010), Yavuz (2010), Ertem ve Turgut (2020)'un yaptı̆̆1 çalışmalar değerlendirilerek çalışmanın ana materyali olan Ortamahalle'de doğal taş kullanımları 3 başlıkta incelenmiştir (Altınçekiç, 2001; Gürdal ve Özgünler, 2010; Yavuz, 2010; Ertem ve Turgut, 2020: 2076-2089) (Tablo 1). Daha sonra gözlem ve arazi çalışmaları yapılmış, araştırma alanına ait fotoğraf ve video çekimleri 


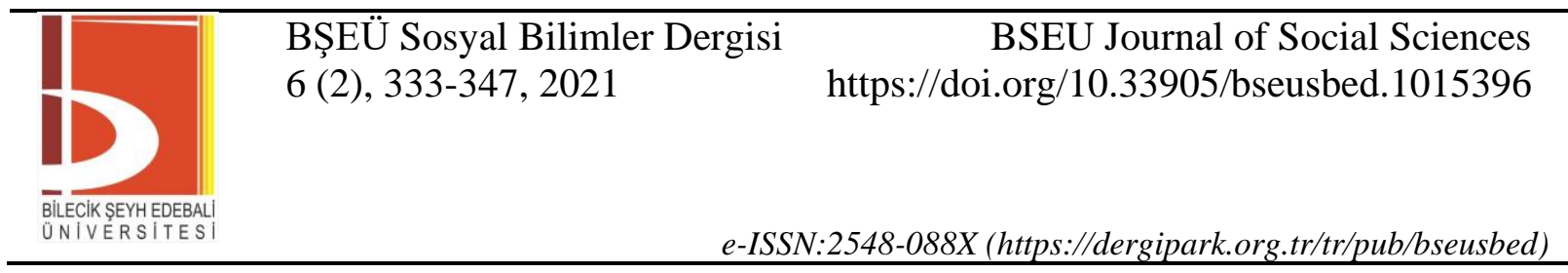

yapılmıştır. Her başlığa dair alandan 4'er fotoğraf toplamda parametrelere ait 12 fotoğraf seçilmiştir (Tablo 2). Üçüncü aşamada ise bu iki aşamanın ardından sayısal verilerin oluşturulması aşaması gerçekleştirilmiş ve peyzaj değeri ölçülmüştür. Peyzaj değeri ölçülme aşamasında Clay ve Smidt, 2004; Müderrisoğlu ve Eroğlu, 2006; Bulut ve Yılmaz, 2008; Acar ve Sakıcı, 2008; Acar ve Güneroğlu, 2009; Güneroğlu 2017'nin yaptığı çalıșmalar değerlendirilerek parametreler oluşturulmuştur (Clay ve Smidt, 2004: 239-255; Müderrisoğlu ve Eroğlu, 2006: 136-146; Bulut ve Yılmaz, 2008: 121-129; Acar ve Sakıc1, 2008: 121-129; Acar ve Güneroğlu, 2009: 65-73; Güneroğlu, 2017: 10-20) (Şekil 7).

Tablo 1.Çalışma kapsamında belirlenen sınıflandırmalar

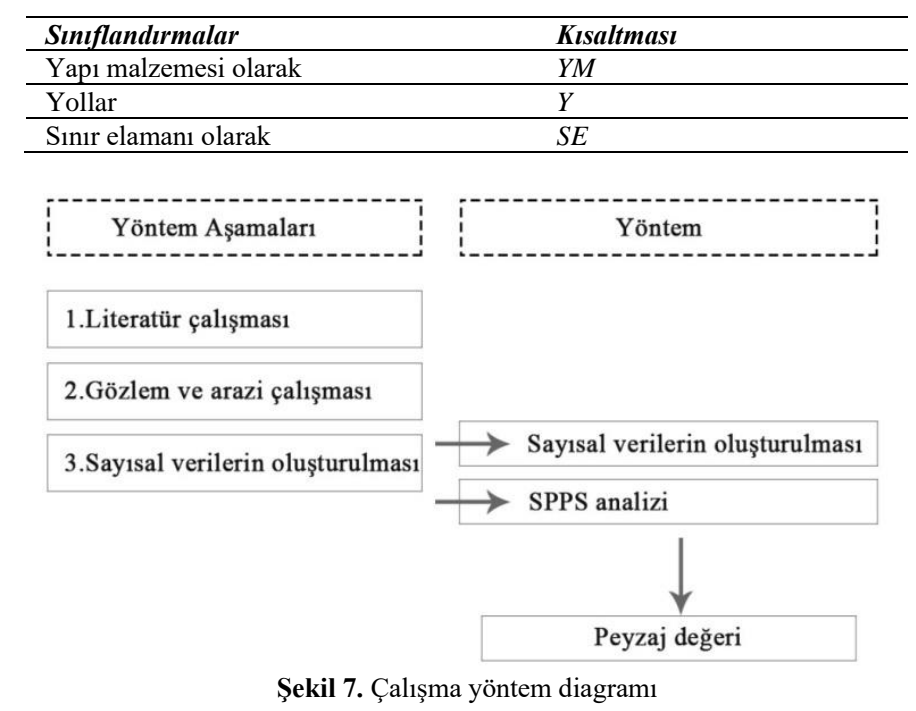

Yöntem kapsamında öncelikli olarak her grup kendi içerisinde uzman gruba puanlatılacak, ardından her gruptan en yüksek puanı alan 1'er örnek toplamda 3 örnek için SPSS çalışması yapılacaktır. SPPS çalışmasının temel amacı en yüksek puanı alan 3 örneğin peyzaj değerinin ölçülmesidir. Yöntemin ilk aşamasını oluşturan bölümde 12 fotoğraf tasarım eğitimi almış 88 kişiye puanlatılmıştır. Uygulamalar uzman gruba puanlatıllıken "resimde gördüğ̈n̈üz doğal taş uygulamasın bir uzman olarak başarılı ve doğru bir uygulama olarak görmekteyim" sorusu üzerine kurgulanmıştır. Sorunun cevabında puanlamalar 5 en yüksek ve 1 en düşük puan olacak şekilde sıralanmıştır. Ardından her gruptan en yüksek puanı alan 3 örnek belirlenmiştir. Belirlenen bu örnekler uzman kişi sayısı arttırılarak peyzaj değerlerini belirleyebilmek adına "likert tutum skalası" ile uzman gruba (118 kişi) tekrar sorgulanmıştır. Peyzaj değerini belirlemek adına yapılan literatür çalışmalardan yararlanılarak 10 parametre belirlenmiştir. Parametreler kendilerini ifade eden 10 soruya çevrilmiş ve her 3 grup içinde sorgulanmıştır. Sorgulanmanın ardından her birinin kendi içlerinde; parametreler arasındaki önem düzeyini belirleyebilmek için faktör analizi, parametrenin istatistiksel olarak anlamlı olup olmadığını belirlemek için 'OneSample T' testi uygulanmış T-testi ve parametrelerin kendi aralarındaki ilişkiyi görebilmek için de korelasyon analizi yapılmıştır. 


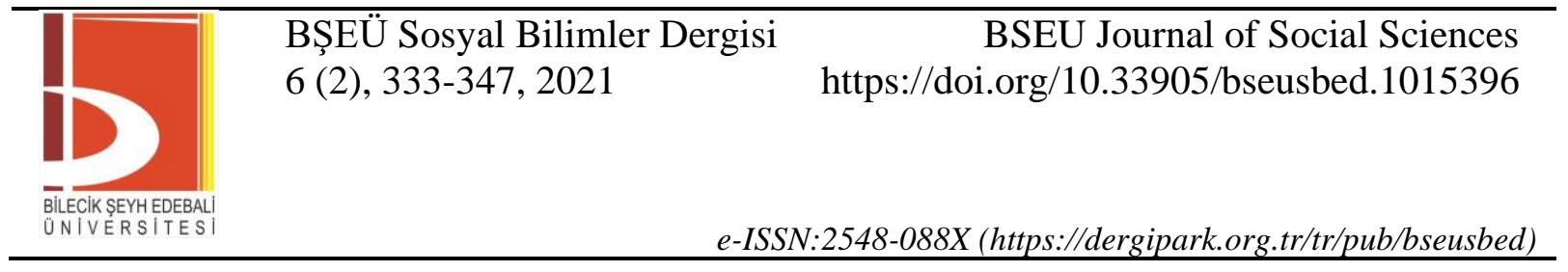

Tablo 2. Alan çalışmasından sonra her grup için çekilen 4'er örnek

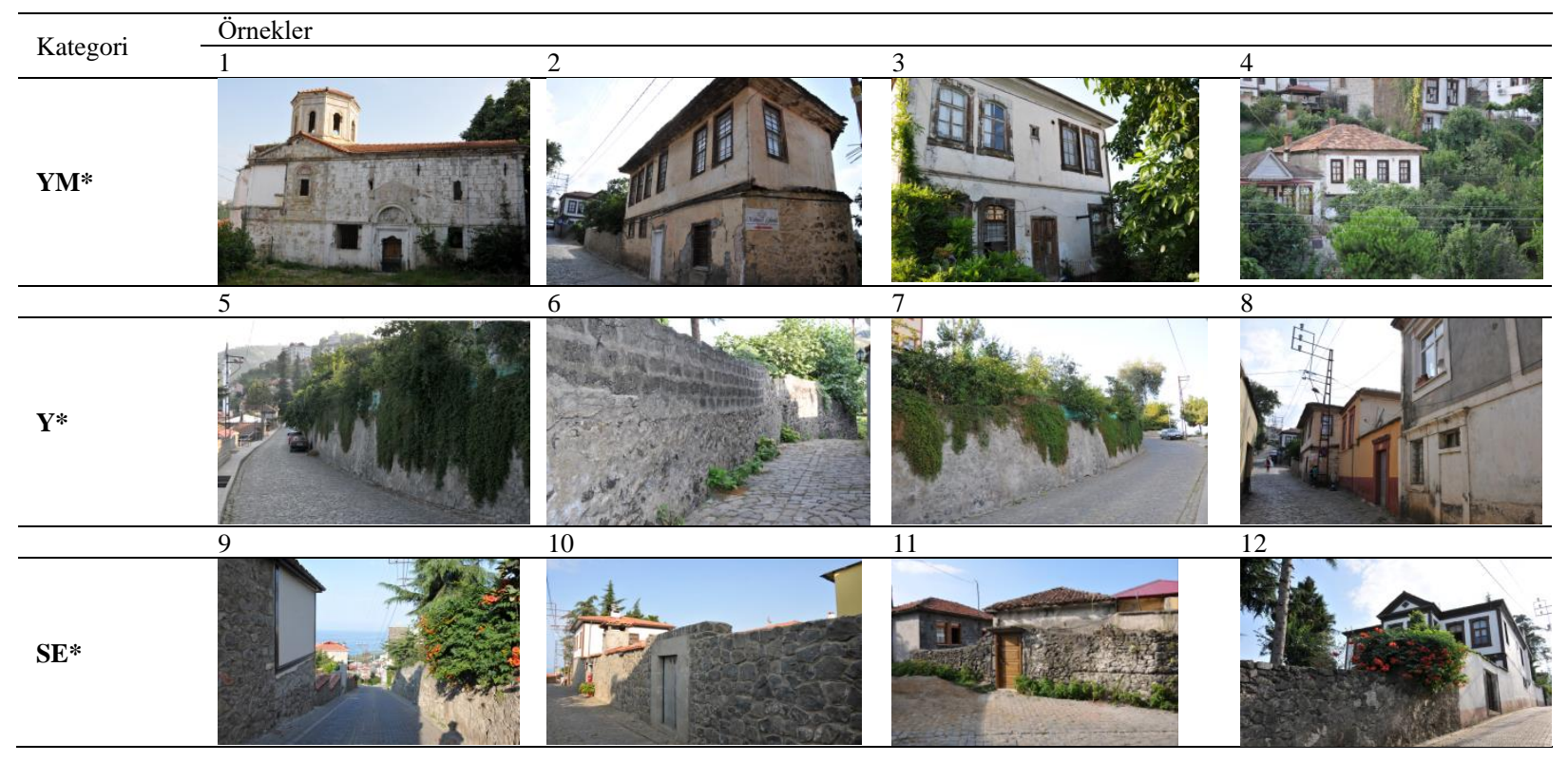

\section{BULGULAR}

Çalışmanın bulgularında öncelikli olarak uygulamaların görselleri puanlatılmıştır. Sonuçlardan elde edilen bulgulara bakıldığında Tablo 3'deki uygulamalar arasından en yüksek puanı alan uygulamalar yapı malzemeleri arasından "örnek 4", sinır elemanları arasından "örnek 5", donatı elemanları arasından ise "örnek 12" olmuştur (Tablo 3, 4). Uygulamalar içerisinden en yüksek puanı alan bu 3 uygulama ile diğer istatistiksel çalışmalar yapılmıştır.

Tablo 3. Uygulamaların puan tablosu

\begin{tabular}{|c|c|c|}
\hline Kategori & Örnek no & Aldığı Puan \\
\hline \multirow{4}{*}{$\begin{array}{l}Y M \\
\text { Yapı malzemesi }\end{array}$} & 1.örnek & 316 \\
\hline & 2.örnek & 247 \\
\hline & 3.örnek & 273 \\
\hline & 4.örnek & 339 \\
\hline \multirow{4}{*}{$\begin{array}{l}\text { Y } \\
\text { Yollar }\end{array}$} & 5.örnek & 305 \\
\hline & 6.örnek & 296 \\
\hline & 7.örnek & 304 \\
\hline & 8.örnek & 213 \\
\hline \multirow{4}{*}{$\begin{array}{l}\text { SE } \\
\text { Sinır elemanı }\end{array}$} & 9.örnek & 344 \\
\hline & 10.örnek & 321 \\
\hline & 11.örnek & 298 \\
\hline & 12.örnek & 369 \\
\hline
\end{tabular}




\begin{tabular}{|c|c|c|}
\hline & $\begin{array}{l}\text { BŞEÜ Sosyal Bilimler Dergisi } \\
6(2), 333-347,2021\end{array}$ & $\begin{array}{r}\text { BSEU Journal of Social Sciences } \\
\text { https://doi.org/10.33905/bseusbed.1015396 }\end{array}$ \\
\hline & $e-I S S$ & V:2548-088X (https://dergipark.org.tr/tr/pub/bseusbed) \\
\hline
\end{tabular}

Tablo 4. Doğal taş uygulama görsellerinden en yüksek puan alan 3 uygulama

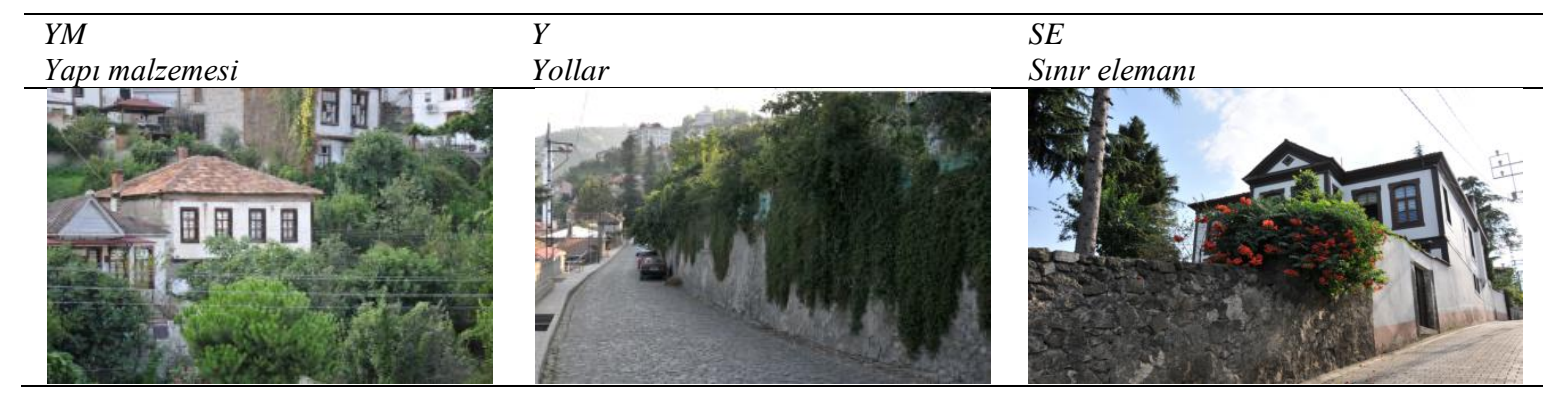

Tablo 4'de yapı malzemesi, yollar ve sınır elemanı arasından en yüksek puanı alan uygulamalar seçilmiştir. Ardından her 3 uygulama içinde "peyzaj değeri bulguları"elde edilmiştir. Bu bulgular aşağıda verilen başlıklar şeklinde elde edilmiştir;

- Yapı malzemesi uygulamasına dair elde edilen peyzaj değeri bulguları

- Yol uygulamasına dair elde edilen peyzaj değeri bulguları

- Sınır elemanı uygulamasına dair elde edilen peyzaj değeri bulguları

\section{A. Yapı Malzemesi Uygulamasına Dair Elde Edilen Peyzaj Değeri Bulguları}

Ortamahalle'de yapı malzemesi olarak doğal taş kullanımlarının peyzaj değerini sayısal veriler ile belirlemek için Tablo 5'de faktör analizi, Tablo 6'da korelasyon ve Tablo 7'de 'One sample T' testi yapılmıştır. Elde edilen bulgulara bakıldığında ise Tablo 5'de faktörler ve her bir değişkenin faktörlerinin altındaki ağırlıkları verilmiştir. Bu sonuçlara bakıldığında 1. faktör grubu altındaki ifadelerin diğer gruplar altındaki ifadelerden daha fazla bir ağırlık olduğu görülmektedir. Bu faktör altındaki en büyük yükü sırasıyla "etkileyici” (.806), "hatırlanabilir” (.738)", "sürekli" (.728)", "bütünlük etkisi” (.720) yüksek yüklü parametreleri takip etmektedir.

Tablo 5. "Seçilen yapı malzemesi üzerinde" peyzaj değeri parametrelerinin faktör analizi sonuçları

\begin{tabular}{lcc}
\hline \multirow{2}{*}{ Değişkenler } & \multicolumn{2}{c}{ Faktör Yükleri } \\
\cline { 2 - 3 } & $\mathbf{1}$ & $\mathbf{2}$ \\
\hline Estetik &, 605 &, 590 \\
\hline Özgün &, 679 &, 545 \\
\hline İşlevsel &, 594 &, 029 \\
\hline Hatırlanabilir & $\mathbf{7 3 8}$ &, 103 \\
\hline Etkileyici & $\mathbf{, 8 0 6}$ &, 296 \\
\hline Uyumlu & $\mathbf{6 4 6}$ &, 295 \\
\hline Doğal & $\mathbf{6 8 9}$ &, 285 \\
\hline Sürekli & $\mathbf{, 7 2 8}$ &, 119 \\
\hline Algılanabilir & $\mathbf{6 8 5}$ &, 372 \\
\hline Bütünlük etkisi & $\mathbf{7 2 0}$ &, 460 \\
\hline
\end{tabular}

Yapı malzemesi uygulaması ve peyzaj değeri arasındaki ilişkiyi belirlemek için korelasyon analizi yapılmıştır. Sonuçta parametreler arasındaki korelasyon analizi ile ilişki durumları belirlenmiştir. Pearson korelasyon katsayıları \%99 önem düzeyinde hesaplanmıştır (Tablo 6). Analiz sonucunda peyzaj parametreleri arasında yer alan "süreklilik" ile beklenti düzeyi ölçüm parametrelerinden olan "uyumlu" parametresi arasında en yüksek korelasyon tespit edilmiştir $\left(\mathrm{r}=.883^{* *}\right)$. Yine peyzaj değeri parametreler arasında yer alan "özgün” ile "doğal" parametresi arasında korelasyon tespit edilmiştir $\left(\mathrm{r}=.870^{* *}\right)$. Üçüncü sırada yüksek oranlı korelasyon "işlevsel” ve "etkileyici” parametreleri arasında ve "işlevsel” ve "bütünlük etkisi” arasında görülmüştür $\left(\mathrm{r}=.866^{* *}\right)$. Tüm verilere ait korelasyon bilgileri Tablo 6’ da verilmiştir. 
Tablo 6. "Seçilen yapı malzemesi üzerinde” peyzaj değeri parametrelerinin korelasyon analizi sonuçları

\begin{tabular}{|c|c|c|c|c|c|c|c|c|c|c|}
\hline & 1 & 2 & 3 & 4 & 5 & 6 & 7 & 8 & 9 & 10 \\
\hline $1 *$ & 1 & & & & & & & & & \\
\hline $2 *$ & $339^{* *}$ & 1 & & & & & & & & \\
\hline 3* &, $671^{* * *}$ &, $554^{* *}$ & 1 & & & & & & & \\
\hline 4* &, $542^{* *}$ &, $117^{*}$ &, $737^{* *}$ & 1 & & & & & & \\
\hline 5* &, $649^{* *}$ &, $526^{* * *}$ &, $866^{* * *}$ &, $658^{* *}$ & 1 & & & & & \\
\hline 6* & $637^{\text {** }}$ &, $143^{*}$ &, $686^{* *}$ &, $542^{* * *}$ &, $500^{* *}$ & 1 & & & & \\
\hline 7* &, $522^{* * *}$ &, $870^{* * *}$ &, $551^{* *}$ &, $194^{* * *}$ &, $575^{* *}$ & $268^{* *}$ & 1 & & & \\
\hline 8* & $498^{\text {** }}$ & ,097 &, $642^{* *}$ &, $739^{* *}$ &, $566^{* *}$ &, $602^{* *}$ &, $147^{* *}$ & 1 & & \\
\hline 9* &, $564^{* *}$ & $162^{* *}$ &, $813^{* *}$ &, $\mathbf{8 8 3}^{* *}$ &, $792^{* * *}$ &, $554^{* *}$ & $194^{* *}$ &, $674^{* *}$ & 1 & \\
\hline $10^{*}$ & $460^{* *}$ &, $559^{* *}$ &, $866^{* * *}$ &, $739^{* *}$ &, $672^{* *}$ &, $559^{* * *}$ &, $543^{* *}$ &, $549^{* *}$ &, $700^{* * *}$ & 1 \\
\hline
\end{tabular}

1.Estetik, 2.Özgün, 3.İslevsel, 4.Hatırlanabilir, 5.Etkileyici, 6.Uyumlu, 7.Doğal, 8.Sürekli, 9.AlgılanabiliR, 10.Bütünlük etkisi

Çalışma kapsamında sayısal verilerde kullanılan 10 parametrenin istatistiksel olarak anlamlı olup olmadığını belirlemek için SPSS kullanılarak 'One-Sample T' testi uygulanmıştır. Test sonuçlarına bakıldığında "sürekli”, "doğal” ve "etkileyici”" parametreleri istatiksel olarak anlamlı çıkan parametrelerdir $(p<0.01)($ Tablo 7).

Tablo 7. "Seçilen yapı malzemesi üzerinde” peyzaj değeri parametrelerinin ‘One-Sample T’testi sonuçları

\begin{tabular}{lccccc}
\hline & & & & \multicolumn{2}{c}{$95 \%$ Güven aralı̆ı } \\
\hline & $\mathbf{t}$ & Standart Sapma & Ortalama Değer & Alt Sinır & Üst Sınır \\
\hline Estetik & 21,164 & 1,10917 & 2,1610 & 1,9588 & 2,3632 \\
\hline Özgün & 23,153 & 1,18885 & 2,5339 & 2,3172 & 2,7506 \\
\hline İșlevsel & 23,719 &, 91983 & 2,0085 & 1,8408 & 2,1762 \\
\hline Hatırlanabilir & 22,069 &, 95941 & 1,9492 & 1,7742 & 2,1241 \\
\hline Etkileyici & $\mathbf{2 3 , 7 2 6}$ & 1,09415 & 2,3898 & 2,1904 & 2,5893 \\
\hline Uyumlu & 23,526 &, 88826 & 1,9237 & 1,7618 & 2,0857 \\
\hline Doğal & $\mathbf{2 3 , 9 2 6}$ &, 84646 & 1,8644 & 1,7101 & 2,0187 \\
\hline Sürekli & $\mathbf{2 4 , 4 8 2}$ &, 96637 & 2,1780 & 2,0018 & 2,3541 \\
\hline Algılanabilir & 21,659 &, 98184 & 1,9576 & 1,7786 & 2,1366 \\
\hline Bütünlük etkisi & 22,729 &, 86676 & 1,8136 & 1,6555 & 1,9716 \\
\hline
\end{tabular}

\section{B. Yol Uygulamasına Dair Elde Edilen Peyzaj Değeri Bulguları}

Çalışmada doğal taşın yol uygulamalarında kullanımlarının peyzaj değerini sayısal veriler ile belirlemek için Tablo 8'de faktör analizi, Tablo 9'da korelasyon ve Tablo 10'de 'One-Sample T' testi yapılmıştır. Elde edilen bulgulara bakıldığgnda ise Tablo 8'de faktörler ve her bir değişkenin faktörlerinin altındaki ağırlıkları verilmiştir.

$\mathrm{Bu}$ sonuçlara bakıldığında 1. faktör grubu altındaki ifadelerin diğer gruplar altındaki ifadelerden daha fazla bir ağırlık olduğunu görebilmekteyiz. Bu faktör altındaki en büyük yükü sırasıyla "bütünlük etkisi” (.802), “doğal” (.731)”, "uyumlu” (.728)”, “sürekli” (.721) yüksek yüklü parametreler arasındadır. 


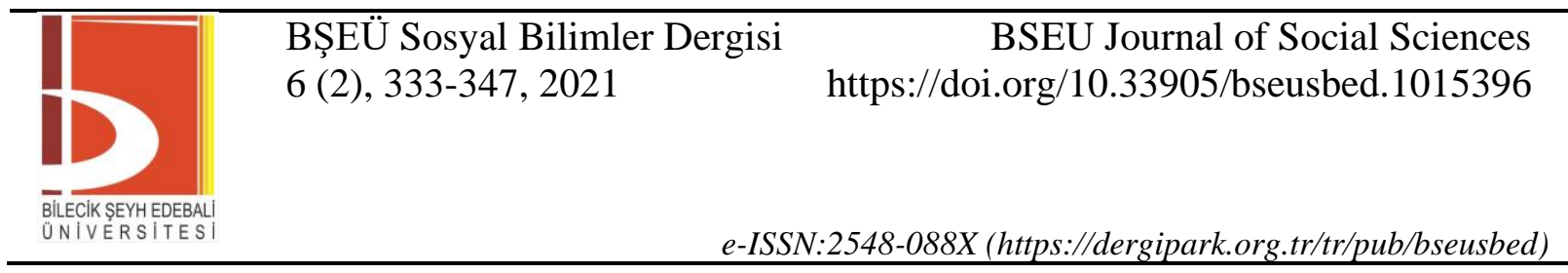

Tablo 8. "Seçilen yol uygulaması üzerinde” peyzaj değeri parametrelerinin faktör analizi sonuçları

\begin{tabular}{lcc}
\hline \multirow{2}{*}{ Değişkenler } & Faktör Yükleri & \\
\cline { 2 - 3 } Estetik & 1 & 2 \\
\hline Özgün &, 255 &, 805 \\
\hline İşlevsel &, 230 &, 810 \\
\hline Hatırlanabilir &, 502 &,- 035 \\
\hline Etkileyici &, 757 &, 000 \\
\hline Uyumlu &, 439 &, 002 \\
\hline Doğal & $\mathbf{7 3 1}$ &,- 178 \\
\hline Sürekli & $\mathbf{7 2 8}$ &, 111 \\
\hline Algılanabilir & $\mathbf{7 2 1}$ &,- 193 \\
\hline Bütünlük etkisi & $\mathbf{6 6 5}$ &,- 139 \\
\hline
\end{tabular}

Yol uygulaması ve peyzaj değeri arasındaki ilişkiyi belirlemek için korelasyon analizi yapılmıştır. Sonuçta parametreler arasındaki korelasyon analizi ile ilişki durumları belirlenmiştir. Pearson korelasyon katsayıları \%99 önem düzeyinde hesaplanmıştır (Tablo 9).

Analiz sonucunda peyzaj değeri parametreleri arasında yer alan "estetik" ve "işlevsel” parametresi arasında en yüksek korelasyon tespit edilmiştir $\left(\mathrm{r}=.864^{* *}\right)$. Yine peyzaj değeri parametreler arasında yer alan "özgün” ile "doğal” parametresi arasında korelasyon tespit edilmiştir $\left(\mathrm{r}=.809^{* *}\right)$. Üçüncü sirada yüksek oranlı korelasyon "hatırlanabilir" ve "sürekli" parametreleri arasında görülmüştür $\left(\mathrm{r}=.686^{* *}\right)$. Tüm verilere ait korelasyon bilgileri Tablo 9' da verilmiştir.

Tablo 9. "Seçilen yol uygulaması üzerinde" peyzaj değeri parametrelerinin korelasyon analizi sonuçları

\begin{tabular}{|c|c|c|c|c|c|c|c|c|c|c|}
\hline & 1 & 2 & 3 & 4 & 5 & 6 & 7 & 8 & 9 & 10 \\
\hline $1 *$ & 1 & & & & & & & & & \\
\hline $2 *$ &, $559 * *$ & 1 & & & & & & & & \\
\hline 3* &, $864 * *$ &, $463 * *$ & 1 & & & & & & & \\
\hline 4* &, $631 * *$ &, $519 * *$ &, $483 * *$ & 1 & & & & & & \\
\hline 5* &,- 011 &, 086 &,$- 247 * *$ & ,007 & 1 & & & & & \\
\hline 6* & ,397** & ,223** &, $453 * *$ & $268^{* *}$ &,$- 484^{* *}$ & 1 & & & & \\
\hline $7 *$ & ,664** &, $809 * *$ &, $576^{* * *}$ &, $602^{* *}$ &,$- 171^{* *}$ &, $147^{* *}$ & 1 & & & \\
\hline 8* &, $800 * *$ &, $608 * *$ & ,786** &, $686^{* *}$ &,$- 168^{* *}$ &, $551^{* *}$ &, $642^{* *}$ & 1 & & \\
\hline $9 *$ &, $734 * *$ &, $606^{* *}$ &, $665 * *$ &, $554^{* *}$ &, 070 &, $194^{* *}$ &, $674^{* * *}$ &,- 031 & 1 & \\
\hline $10 *$ & ,006 &,- 235 &, 060 &,- 126 &, 049 &, 010 &,$- 193^{*}$ &,- 031 &,- 090 & 1 \\
\hline
\end{tabular}

Çalışma kapsamında sayısal verilerde kullanılan 10 parametrenin “yol uygulaması” kategorisi üzerinde istatistiksel olarak anlamlı olup olmadığını belirlemek için SPSS kullanılarak 'One-Sample T' testi uygulanmıştır. Test sonuçlarına bakıldığında "sürekli”, "bütünlük etkisi” ve "estetik” parametreleri istatiksel olarak anlamlı çıkan parametrelerdir $(\mathrm{p}<0.01)$ (Tablo 10). 


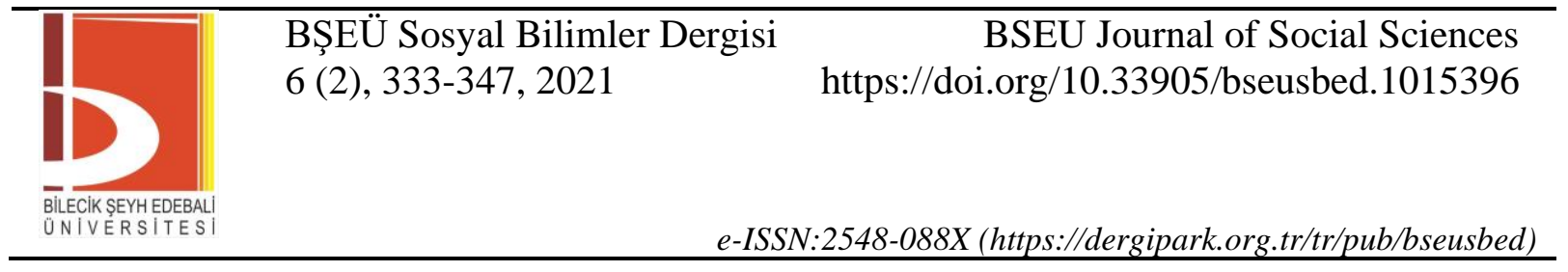

Tablo 10. "Seçilen yol uygulaması üzerinde" peyzaj değeri parametrelerinin t-testi sonuçları

\begin{tabular}{|c|c|c|c|c|c|}
\hline & & & \multicolumn{3}{|c|}{ 95\% Güven Aralığ1 } \\
\hline & $\mathbf{t}$ & Standart Sapma & Ortalama Değer & Alt Sınır & Üst Sınır \\
\hline Estetik & 24,356 & ,93358 & 2,09322 & 1,9230 & 2,2634 \\
\hline Özgün & 22,099 & 1,22472 & 2,49153 & 2,2682 & 2,7148 \\
\hline İşlevsel & 23,904 & ,92814 & 2,04237 & 1,8732 & 2,2116 \\
\hline Hatırlanabilir & 22,889 & ,93308 & 1,96610 & 1,7960 & 2,1362 \\
\hline Etkileyici & 17,407 & 1,13703 & 1,82203 & 1,6147 & 2,0293 \\
\hline Uyumlu & 23,944 &, 86122 & 1,89831 & 1,7413 & 2,0553 \\
\hline Doğal & 22,205 & ,97840 & 2,00000 & 1,8216 & 2,1784 \\
\hline Sürekli & 24,913 &, 89054 & 2,04237 & 1,8800 & 2,2047 \\
\hline Algilanabilir & 22,808 & ,89200 & 1,87288 & 1,7103 & 2,0355 \\
\hline Bütünlük etkisi & 24,387 &, 78893 & 1,77119 & 1,6274 & 1,9150 \\
\hline
\end{tabular}

\section{Sınır Elemanı Uygulamasına Dair Elde Edilen Peyzaj Değeri Bulgulart}

Çalışmada doğal taşın yol uygulamalarında kullanımlarının peyzaj değerini sayısal veriler ile belirlemek için Tablo 11'de faktör analizi, Tablo 12'da korelasyon ve Tablo 13'de 'One-Sample T' testi yapılmıştır. Elde edilen bulgulara bakıldığında ise Tablo 11'de faktörler ve her bir değişkenin faktörlerinin altındaki ağırlıkları verilmiştir.

Bu sonuçlara bakıldığında 1. faktör grubu altındaki ifadelerin diğer gruplar altındaki ifadelerden daha fazla bir ağırlık olduğu görülmektedir. Bu faktör altındaki en büyük yükü sırasıyla "uyumlu” (.792).,"algılanabilir", (.721), “sürekli” (.705), “doğal” (.681) yüksek yüklü parametreler takip etmektedir.

Tablo 11. "Seçilen sınır elemanı üzerinde" peyzaj değeri parametrelerinin faktör analizi sonuçları

\begin{tabular}{lcc}
\hline \multirow{2}{*}{ Değișkenler } & \multicolumn{2}{c}{ Faktör Yükleri } \\
\cline { 2 - 3 } Estetik & 197 &, 794 \\
\hline Özgün &, 195 &, 755 \\
\hline İşlevsel &, 624 &,- 227 \\
\hline Hatırlanabilir &, 674 &, 259 \\
\hline Etkileyici &, 502 &, 420 \\
\hline Uyumlu & $\mathbf{, 7 9 2}$ &,- 236 \\
\hline Doğal & $\mathbf{6 8 1}$ &, 026 \\
\hline Sürekli & $\mathbf{, 7 0 5}$ &,- 346 \\
\hline Algılanabilir & $\mathbf{7 2 1}$ &, 014 \\
\hline Bütünlük etkisi &, 559 &,- 259 \\
\hline
\end{tabular}

Doğal taşın sınır elemanı ve peyzaj değeri arasındaki ilişkiyi belirlemek için korelasyon analizi yapılmıştır. Sonuçta parametreler arasındaki korelasyon analizi ile ilişki durumları belirlenmiştir. Pearson korelasyon katsayıları \%99 önem düzeyinde hesaplanmıştır (Tablo 9).

Analiz sonucunda peyzaj değeri parametreleri arasında yer alan "etkileyici” ve "algılanabilir" parametresi arasında en yüksek korelasyon tespit edilmiştir $\left(\mathrm{r}=.888^{* *}\right)$. Yine peyzaj değeri parametreler arasında yer alan "uyumlu" ile "sürekli" parametresi arasında korelasyon tespit edilmiştir $\left(\mathrm{r}=.866^{* *}\right)$. Üçüncü sırada yüksek oranlı korelasyon "estetik" ve "işlevsel” parametreleri arasında görülmüştür ( $\left.\mathrm{r}=.856^{* *}\right)$. Tüm verilere ait korelasyon bilgileri Tablo 12’ de verilmiştir. 
Tablo 12. "Seçilen sınır elemanı üzerinde" peyzaj değeri parametrelerinin korelasyon analizi sonuçları

\begin{tabular}{|c|c|c|c|c|c|c|c|c|c|c|}
\hline & 1 & 2 & 3 & 4 & 5 & 6 & 7 & 8 & 9 & 10 \\
\hline $1 *$ & 1 & & & & & & & & & \\
\hline $2 *$ &, $448^{* *}$ & 1 & & & & & & & & \\
\hline $3 *$ & $856^{* *}$ & $463^{* *}$ & 1 & & & & & & & \\
\hline $4 *$ &, $633^{* *}$ &, $519^{* *}$ &, $483^{* *}$ & 1 & & & & & & \\
\hline $5^{*}$ &, $913^{* *}$ &, $559^{* *}$ &, $864^{* *}$ &, $631^{* *}$ & 1 & & & & & \\
\hline 6* &, $643^{* *}$ &, $474^{* *}$ &, $601^{* *}$ &, $500^{* *}$ &, $636^{* *}$ & 1 & & & & \\
\hline $7 *$ &,- 064 & ,086 &,$- 247^{* *}$ & ,007 &,- 011 &,$- 278^{* *}$ & 1 & & & \\
\hline 8* &, $802^{* *}$ &, $608^{* * *}$ &, $786^{* *}$ &, $686^{* *}$ &, $800^{* *}$ &, $866^{* *}$ &,$- 168^{* *}$ & 1 & & \\
\hline $9 *$ &, $846^{* * *}$ &, $528^{* *}$ &, $862^{* *}$ &, $621^{* *}$ &, $888^{* *}$ &, $634^{* *}$ &,- 050 &, $855^{* *}$ & 1 & \\
\hline $10^{*}$ &, $445^{* *}$ &, $202^{* *}$ &, $220^{* *}$ &, $488^{* *}$ &, $531^{* *}$ &, $371^{* *}$ &, $424^{* *}$ &, $400^{* *}$ &, $445^{* *}$ & 1 \\
\hline
\end{tabular}

1.Estetik, 2.Özgün, 3.Işslevsel, 4.Hatırlanabilir, 5.Etkileyici, 6.Uyumlu, 7.Doğal, 8.Sürekli, 9.AlgılanabiliR, 10.Bütünlük etkisi

Çalışma kapsamında sayısal verilerde kullanılan 10 parametrenin "sınır elemanı” kategorisi üzerinde istatistiksel olarak anlamlı olup olmadığını belirlemek için SPSS kullanılarak 'One-Sample T' testi uygulanmıştır. Test sonuçlarına bakıldığında "işlevsel”, "sürekli” ve "algılanabilir” parametreleri istatiksel olarak anlamlı çıkan parametrelerdir $(\mathrm{p}<0.01)$ (Tablo 13).

Tablo 13. "Seçilen sınır elemanı üzerinde” peyzaj değeri parametrelerinin 'One-Sample T'-testi sonuçları

\begin{tabular}{lccccc}
\hline & & & & \multicolumn{2}{c}{ 95\% Güven aralı̆̆ } \\
\hline Estetik & 23,888 &, 94802 & 2,0847 & 1,9119 & 2,2576 \\
\hline Özgün & 22,436 & 1,14478 & 2,3644 & 2,1557 & 2,5731 \\
\hline İşlevsel & $\mathbf{2 6 , 2 8 2}$ &, 85464 & 2,0678 & 1,9120 & 2,2236 \\
\hline Hatırlanabilir & 22,325 & 1,03089 & 2,1186 & 1,9307 & 2,3066 \\
\hline Etkileyici & 21,303 & 1,19272 & 2,3390 & 2,1215 & 2,5564 \\
\hline Uyumlu & 22,757 & 1,02345 & 2,1441 & 1,9575 & 2,3307 \\
\hline Doğal & 23,595 &, 90518 & 1,9661 & 1,8011 & 2,1311 \\
\hline Sürekli & $\mathbf{2 4 , 8 7 7}$ &, 97324 & 2,2288 & 2,0514 & 2,4062 \\
\hline Algılanabilir & $\mathbf{2 4 , 2 6 6}$ &, 89152 & 1,9915 & 1,8290 & 2,1541 \\
\hline Bütünlük etkisi & 20,946 & 1,12949 & 2,1780 & 1,9720 & 2,3839 \\
\hline
\end{tabular}

Çalışmanın son aşamasında ise tarihi doku ve doğal taş uyumunu sorgulayabilmek adına 5 soru sorulmuştur. Elde edilen sonuçlar Tablo 14'de verilmiştir. Sonuçlara bakıldığında ise; neredeyse tüm sorularda "evet" yanıtı öne geçmiştir. Sonuçlarda, "Doğal taş kullanımını tarihi yapı ile özdeşleştiğini düşünmekteyim" sorusuna \%87 "evet”, \%5 ise "hayır" cevabı, "Doğal taş kullanımını modern yapılara da çok yakıştırıyorum" sorusuna \%84 "evet”, \%18 ise "hayır" cevab1, "Doğal taş kullanımlarl arttırlmalıdır" sorusuna \%89 "evet”, \%5 ise "hayır” cevab1, "Doğal taş kullanımını daha çok tarihi sokaklarda görmekteyim” sorusuna \% 85 “evet”, \%5 ise "hayır” cevabı, “Doğal taş kullanımını tarihi sokaklar ile özdeşleştiğini düşünmekteyim” sorusuna \%89 “evet”, \%5 ise "hayır" cevabı alınmıştır (Tablo 14).

Tablo 14. Katılımcıların doğal taş ve tarihi sokaklar arasındaki bağlantıya dair

\begin{tabular}{|c|c|c|c|c|c|c|}
\hline \multirow{2}{*}{ Sorular } & \multicolumn{2}{|c|}{ Evet } & \multicolumn{2}{|c|}{ Fikrim yok } & \multicolumn{2}{|c|}{ Hayır } \\
\hline & Frekans & Yüzde (\%) & Frekans & Yüzde (\%) & Frekans & Yüzde (\%) \\
\hline $1 *$ & 105 & 87 & 8 & 7 & 5 & 4 \\
\hline $2 *$ & 84 & 71 & 16 & 14 & 18 & 15 \\
\hline $3 *$ & 105 & 89 & 8 & 7 & 5 & 4 \\
\hline $4 *$ & 100 & 85 & 13 & 11 & 5 & 4 \\
\hline $5 *$ & 105 & 89 & 8 & 7 & 5 & 4 \\
\hline \multicolumn{7}{|c|}{$\begin{array}{l}\text { 1*: Doğal taş kullanımını tarihi yapı ile özdeşleştiğini düşünmekteyim } \\
2 * \text { Doğal taş kullanımını modern yapılara da çok yakıştırıyorum } \\
3 *: \text { Doğal taş kullanımları arttırılmalıdır } \\
4 *: \text { Doğal taş kullanımını daha çok tarihi sokaklarda görmekteyim } \\
5 * \text { Doğal taş kullanımını tarihi sokaklar ile özdeşleştiğini düşünmekteyim }\end{array}$} \\
\hline
\end{tabular}




\section{SONUÇLAR VE ÖNERILER}

Tarih, medeniyet, mimari, kültür, peyzaj vb. birçok kavramla ilişkili olan, çok yönlü kullanıma sahip doğal taşlar fiziksel özelliklerine uygun mekanlarda kullanıldıklarında işlevsel, dayanıklı ve estetik bir malzemedir. Doğal malzemelerin kullanılması açısından Türkiye de önemli doğal taş rezervlerine sahiptir. Yapılan bu çalışma kapsamında elde edilen sonuçlarda 3 grupla ifade edilmiştir. Bunlar yapı malzemesi uygulaması, yol uygulaması ve sinır elemanı uygulamasidır.

\section{A. Yapı Malzemesi Uygulamasına Dair Elde Edilen Sonuçlar;}

- Faktör analizi sonucunda en büyük yükü “etkileyici (.806)” parametresi almıştır (Tablo 5). Doğal taşın kullanışlı ve doğal olması bu parametrenin sonucunu etkilediği düşünülmektedir.

- Diğer yüksek yüklü parametreler "hatırlanabilir, sürekli, bütünlük etkisi” parametrelerdir. Bu parametrelere bakıldığında fonksiyonel özellikleri simgelediği görülmektedir. Doğal taşın fonksiyonel ve işlevsel olması katılımcıların da bu cevapları vermesinde etkili olduğu ön görülmektedir. Ayrıca kent kimliğinde belirleyici eleman olduğu sonucuna varılabilir.

- Yapı malzemesi uygulaması ve peyzaj değeri arasındaki ilişsiyi belirleyen korelasyon analizi sonuçlarına göre; süreklilik/uyumlu, özgün/doğal parametresi arasında ve işlevsel/etkileyici parametreleri arasında ilişki olduğu gözlemlenmiştir (Tablo 6).

- 'One-Sample T' test sonuçlarına bakıldığında “doğal, sürekli, etkileyici” parametreleri istatiksel olarak anlamlı çıkmıştır. Bu parametreler doğal taşın hem estetik hem de işlevsel özellikleri arasında anlamlı bir bağ olduğunu ifade etmektedir.

\section{B. Yol Uygulamasına Dair Elde Edilen Sonuçlar}

- Yol uygulamasına dair peyzaj değeri ölçümlerinde faktör analizi sonucunda en büyük yükü “bütünlük etkisi, doğal, uyumlu, sürekli” parametreleri almıştır. Doğal taşın dokusundaki birlik ve denge unsurları bu değerlerin sonucunu etkilediği düşünülmektedir.

- Korelasyon analizi sonucunda "estetik/işlevsel, özgün/doğal ve hatırlanabilir/sürekli parametreleri arasında ilişki görülmüştür (Tablo 9).

- "Sürekli, bütünlük etkisi ve estetik" parametreleri istatiksel olarak anlamlı çıkan parametrelerdir (Tablo 10). Bu parametreler ve doğal taş yol uygulamaları arasında bir ilişki olduğu görülmektedir.

\section{Stnır Elemanı Uygulamasina Dair Elde Edilen Sonuçlar;}

- En yüksek faktör yükü "uyumlu, algılanabilir, sürekli, doğal” parametreleridir (Tablo 11).

- Korelasyon analizi sonucunda etkileyici/algılanabilir, uyumlu/sürekli parametreleri arasında yüksek bir korelasyon ilişkisi tespit edilmiştir (Tablo 12).

- One-Sample T' testi sonuçlarında sınır elemanı uygulamasına dair “özgün, işlevsel, sürekli, alg1lanabilir" parametreleri istatiksel olarak anlamlı olduğu görülmüştür (Tablo 13).

\section{Genel Sonuçlara Bakıldı̆̆ında Katılımcılar;}

- Doğal taş kullanımını tarihi yapı ile özdeşleştiğini düşünmektedir.

- Doğal taş kullanımını modern yapılara da çok yakıştırmaktadır.

- Doğal taş kullanımları arttırılmasını istemektedir.

- Doğal taş kullanımını daha çok tarihi sokaklarda görmektedirler.

- Doğal taş kullanımını tarihi sokaklar ile özdeşleştiğini düşünmektedirler.

- Doğal taş varlığı kent kimliğinin algılanabilir ve hatırlanabilir olduğunu göstermektedir (Tablo 14).

Bu sonuçlara göre böylesine tarihsel geçmişe sahip olan doğal taşlar günümüzde de halen tasarımların en temel elemanlarından biri olma özelliği sürdürülebilirliği destekler niteliktedir. Özgün ve geleneksel malzemenin korunması ve geleceğe aktarılması için yapılan bu çalışma ileride yapılacak çalışmalar için örnek teşkil etmektedir. Doğal taş yapılan bu çalışma kapsamında değerlendirilen üç seçenek için de "estetik" ve "fonksiyonel" bulunmuştur. Neredeyse peyzaj değerinin birçok parametresi yapılan uygulamalarda yüksek değerde çıkmıştır. Bu 
BŞEÜ Sosyal Bilimler Dergisi

6 (2), 333-347, 2021
BSEU Journal of Social Sciences

https://doi.org/10.33905/bseusbed.1015396

sonuçlara göre doğal taş geçmişten günümüze gelen "modern ve tarihi çevre" arasındaki en önemli mimari unsurlardandır denilebilir. Bu kapsamda öneriler şu şekilde sıralanabilir;

- Tarihi yapıların onarımında veya modern yapı inşasında doğal taşların kullanımına ağırlık verilmeli

- Kent kimliğine olumlu katkıları peyzaj tasarımlarında öne çıkarılmalı, vurgu ya da odak nokta olarak doğal taş malzemeli yapılar seçilmeli

- Kentsel alanlarda doğal taşın samimi, sıcak ve doğal etkisinden insanların faydalanmasına yönelik peyzaj tasarımları yapılmalı

- Tasarımcı tarafından doğal taş daha iyi tanınmalı, özellikle tasarım sürecinde doğal taşın estetik ve işlevsel özellikleri öğrenilmeli

- Doğal taş uygulama ekipleri tarafindan teknik uygulama yöntemleri bilinmeli

- Kısıtlı doğal kaynakların kullanımı noktasında en iyi malzeme olduğu kabul edilmelidir.

Sonuç olarak doğal taşlar sürdürülebilir tasarım konseptine uygun olarak kentsel alanlarda yapısal malzeme olarak değerlendirilebilir. Bu durum önemli doğal taş rezervlerine sahip Türkiye için ticari ve ekonomik anlamda fayda sağlayacaktır. Ayrıca doğal taş sektörünün sorumlu kurum ve kuruluşlar tarafından desteklenmesi önem arz etmektedir.

\section{KAYNAKLAR}

Acar C., \&Güneroğlu A.N. (2009). Trabzon kentindeki çizgisel bitki kompozisyonlarının tür çeşitliliği ile işlevsel ve görsel değerleri üzerine bir araştırma.Ekoloji dergisi, Trabzon, 18 (72). 65-73

Acar, C., \&Sakıcı, Ç. (2008) Assessing Landscape Perception of Urban Rocky Habitats.Building and Environment. 43, 1153-1170.

Akçaabat Belediyesi (2021). Ortamahalle [Erişim: 2021, https://www.akcaabat.bel.tr/turizm-rehberidetay.aspx?id=1]

Alptekin, G. (2021). Sürdürülebilirlik Bağlamında Marmara Mermeri ve Güncel Tasarım Örnekleri. Online Journal of Art and Design, 9(4), 303-318.

Altınçekiç, H. (2001). Bazı Dogal Taşların İrdelenmesi ve Peyzaj Düzenlemelerinde Kullanım Olanakları.Istanbul Üniversitesi Orman Fakültesi Dergisi, 51(1), 49-58.

Aydın, Ö., \&Alemdă̆, E. L. (2014). Karadeniz Geleneksel Mimarisinde Sürdürülebilir Malzemeler; Ahşap ve Taş.Uluslararast Sosyal Araştırmalar Dergisi, 7 (35), 394-405.

Bekar, M., Pulatkan, M., \&Güneroğlu, N. (2017). Tarihi Bir Sokak Analizi Trabzon "Orta Mahalle" Örneği. Akademik Sosyal Araştırma Dergisi, 44, 487-503.

Bulut, Z., \&Yılmaz, H. (2008). Determination of landscape beauties through visual quality assessment method: a case study for Kemaliye (Erzincan/Turkey).Environ. Moni.t Assess, 141: 121-129.

Büyükmıhçı, G., Salgın, B., \& Özkan, A. (2015). Yeşil Çatı Çözümlerinin Tarihi Dokularda Geleneksel Çatı Örtüsü Olarak Uygulanabilirliği Üzerine Bir İnceleme.Erciyes Üniversitesi Fen Bilimleri Enstitüsü Dergisi, 31(2): 163-171.

Carta, L., Calcaterra, D., Piergiulio, C., Cappelletti, P., Langella, A., \& Gennaro, M. (2005). The stone materials in the historical architecture of the ancient centerof Sassari: distribution and state of conservation.Journal of Cultural Heritage, 6, 277-286.

Clay, G. R., \&Smidt, R. K. (2004) Assessing the validity and reliability of descriptor variables used in scenic highway analysis.Landscape and Urban Planning, 66 (4): 239-255

Çelik, M.Y., \&Kavuşan, G. (2001). Doğal Taş ve Mermerlere Uygulanan Yüzey Şekillendirme Teknikleri, 4.Endüstriyel Hammaddeler Sempozyumu, İzmir.

Çelik, M. Y. (2003). Dekoratif Doğal Yapı Taşlarının Kullanım Alanları ve Çeşitleri, Madencilik, 42(1), 3-15.

Erdoğan, E. (2006). Çevre ve Kent Estetiği.ZKÜ Bartın Orman Fakültesi Dergisi, 8(9), 68-77. 


\section{BŞEÜ Sosyal Bilimler Dergisi}

6 (2), 333-347, 2021
BSEU Journal of Social Sciences

https://doi.org/10.33905/bseusbed.1015396

Ertem, Z.K., \&Turgut, H. (2020). Kültürel Peyzaj Planlaması Kapsamında Tarihi Çevrelere Yönelik Kentsel Tasarım Önerileri: Tarihi İspir Kalesi ve İspir Evleri.Iğdır Üniversitesi Fen Bilimleri Enstitüsü Dergisi, 10(3): 2076-2089.

Güneroğlu, N. (2017). Akarsu Rehabilitasyonunun Peyzaj Kalitesi Üzerindeki Etkileri. Artvin Çoruh Üniversitesi Orman Fakültesi Dergisi, 18(1). 10-20.

Gürdal, E., \& Acun Özgünler, S. (2016). Tarihi Yapıların Onarımında Doğal Taş Seçimi ve Kullanımı.Restorasyon ve Konservasyon Çalışmaları Dergisi, 16, 27-35.

Hasbay, U., \& Hattap, S. (2017). Doğal Taşlardaki Bozunma (Ayrışma) Türleri ve Nedenleri.Munzur Üniversitesi Bilim ve Gençlik Dergisi, 5 (1), 23-45.

Kan, H. (2009). Tarakl Yerleşimindeki Tarihi Dokunun Sürdürülebilirliği Bağlaminda Kentsel Koruma ve Geliştirme Stratejileri. (Yayımlanmamış Yüksek Lisans Tezi) Bartın Üniversitesi, Fen Bilimleri Enstitüsü, Bartın.

Kap Yücel, S. D., \& Salt, E. (2018). Kültürel Peyzajların tarihsel süreç içerisindeki değişimlerinin tespiti: Bursa İznik örneği. Planlama, 28(1), 40-55.

Karahan, D. S. (2018). Dünyada ve Türkiye'de Doğal Taşlar. Maden Tetkik ve Arama Genel Müdürlüğü, Fizibilite Daire Başkanlığı.

Lynch, K. (2010). Kent Imgesi. Türkiye İş Bankası Kültür Yayınları.

Müderrisoğlu, H, \&Eroğlu, E. (2006) Bazı ibreli ağaçların kar yükü altında görsel algılanmasındaki farkl11ıklar.Süleyman Demirel Üniversitesi Orman Fakültesi Dergisi, A (1): 136-146.

Raju, K., \&Ravinhar, S. (2021). Detailed review on natural stone materials in architecture.Materials Today: Proceedings, 45, 6341-6347

Siegesmund, S., \& Snethlage, R. (2011). Stone in Architecture, Springer, Berlin, Heidelberg.

Yavuz, H. (2010). Doğal Taş Elemanlarının Peyzaj Düzenlemelerinde Kullanımı. (Yayımlanmamış Yüksek Lisans Tezi) İstanbul Teknik Üniversitesi, Fen Bilimleri Enstitüsü, İstanbul.

Yüksel, U., \& Eraslan, Ş. (2019). Jeolojik Miras Niteliğindeki Doğal Taşların Peyzaj Tasarımında Kullanım Olanakları.Mimarlık Bilimleri ve Uygulamaları Dergisi, 4 (1), 69-89. 